\section{'Green Pixie', a Small-seeded, Green Cotyledon, Cream-type Southernpea}

\author{
Richard L. Fery ${ }^{1}$ \\ of Agriculture, 2875 Savannah Highway, Charleston, SC 29414-5334 \\ Additional index words. Vigna unguiculata, cowpea, vegetable breeding
}

U.S. Vegetable Laboratory, Agricultural Research Service, U.S. Department

'Green Pixie' is a new southernpea [Vigna unguiculata (L.) Walp.] that was released on 4 Mar. 1999 by the U.S. Dept. of Agriculture, Agricultural Research Service (USDA, ARS). 'Green Pixie' is a small-seeded, cream-type southernpea that exhibits the green cotyledon trait. The new cultivar produces competitive yields of small peas that can be harvested at the dry stage of maturity without loss of their fresh green color. 'Green Pixie' was developed for use by the frozen food industry, either as a replacement for the popular 'White Acre' or as a substitute for 'Bettergreen' when grown to produce the raw product for a blended pack of 'Bettergreen' and 'White Acre' peas. Unlike 'Bettergreen', the size and shape of 'Green Pixie' peas are quite similar to those of 'White Acre' peas.

\section{Origin}

'Green Pixie' was derived from the cross 'Bettergreen' x 'White Acre' made in 1990. 'Bettergreen' is a cream-type pea with greencolored cotyledons, and 'White Acre' is a cream-type cultivar with cream-colored cotyledons (Fery et al., 1993). Pedigree breeding procedures were used to apply intense pressure in the $F_{2}$ through $F_{8}$ generations to select single plants exhibiting both the green cotyledon trait and 'White Acre' seed characteristics. 'Green Pixie' originated as a bulk of an $F_{9}$ population grown in 1994.

\section{Description}

'Green Pixie' has a high, bushy plant habit similar to that of 'White Acre' (Table 1). 'Green Pixie' produces dry pods at Charleston, S.C., in $\approx 76 \mathrm{~d}$, $5 \mathrm{~d}$ later than 'Bettergreen' and 5 d earlier than 'White Acre' (Table 2). There is no purple pigmentation on the stems, branches, petioles, or peduncles. Flower color is white. Pod set is concentrated, and the pods are borne above the foliage in a scattered fashion. Pods at the "mature green" harvest

Received for publication 15 June 1999. Accepted for publication 19 Oct. 1999. The technical assistance of F.P. Maguire is gratefully acknowledged. The cost of publishing this paper was defrayed in part by the payment of page charges. Under postal regulations, this paper therefore must be hereby marked advertisement solely to indicate this fact. ${ }^{1}$ Research Geneticist. E-mail address: rfery@ awod.com stage are attached to the peduncles at about a manner. Each peduncle typically produces two pods.

A typical 'Green Pixie' pod is slightly curved, $\approx 15 \mathrm{~cm}$ long, and contains $\approx 16$ peas (Fig. 1). Pod color is light green when immature, purple when ready for mature-green har$90^{\circ}$ angle; dry pods are attached in a pendant

Fig. 1. Pods and peas of 'Green Pixie' southernpea. vest, and light straw color when dry. Fresh 'Green Pixie' peas are rhomboidkidney in shape, similar to the shape of fresh 'White Acre' peas, but very different from the ovate to reniform shape characteristic of fresh 'Bettergreen' peas. Dry peas are small and have a smooth seed coat. 'Green Pixie' peas are similar in size to 'White Acre' peas, but much smaller than 'Bettergreen' peas (weight per 100 dry peas: 'Green Pixie', $8.0 \mathrm{~g}$; 'White Acre', $7.9 \mathrm{~g}$; and 'Bettergreen', $10.2 \mathrm{~g})$.

The results of four replicated trials conducted at Charleston, S.C., over a period of 3 years (1996-98) indicate that the average yield of dry peas was $95 \%$ of that of 'White Acre' and $100 \%$ of that of 'Bettergreen' (Table 2). 'Green Pixie' was tested as US-865 throughout the southern United States as an observational entry in 1996 Regional Southernpea Cooperative Trials and as a replicated entry in the 1997 and 1998 trials (28 location-years). During the 2 years of testing as a replicated

Table 1. Plant height, plant width, peduncle length, pod length, and number of peas per pod for 'Green Pixie', 'White Acre', and 'Bettergreen' southernpeas, Charleston, S.C., 1998. ${ }^{\text {' }}$

\begin{tabular}{|c|c|c|c|c|c|}
\hline \multirow[b]{2}{*}{ Cultivar } & \multicolumn{2}{|c|}{ Plant } & \multirow{2}{*}{$\begin{array}{l}\text { Peduncle length } \\
(\mathrm{cm})\end{array}$} & \multirow{2}{*}{$\begin{array}{l}\text { Pod length } \\
(\mathrm{cm})\end{array}$} & \multirow{2}{*}{$\begin{array}{c}\text { Peas/pod } \\
\text { (no.) }\end{array}$} \\
\hline & $\mathrm{Ht}(\mathrm{cm})$ & Width $(\mathrm{cm})$ & & & \\
\hline Green Pixie & $47.3 \mathrm{a}^{\mathrm{y}}$ & $77.6 \mathrm{a}$ & $34.0 \mathrm{a}$ & $14.7 \mathrm{~b}$ & $16.1 \mathrm{a}$ \\
\hline White Acre & $44.2 \mathrm{~b}$ & $78.9 \mathrm{a}$ & $33.4 \mathrm{a}$ & $15.4 \mathrm{a}$ & $16.2 \mathrm{a}$ \\
\hline Bettergreen & $42.1 \mathrm{~b}$ & $75.8 \mathrm{a}$ & $27.4 \mathrm{~b}$ & $14.0 \mathrm{c}$ & $12.2 \mathrm{~b}$ \\
\hline
\end{tabular}

${ }^{2}$ Trial planted on 27 May 1998. The experimental design was a randomized complete-block with 10 replications. Each plot was space-planted, 18 hills per plot, 3 seeds per hill, $30 \mathrm{~cm}$ between hills, and 102 $\mathrm{cm}$ between rows. Each plot was harvested a single time (dry pod stage of maturity).

${ }^{y}$ Mean separation within columns by Student-Newman-Keuls multiple range test, $P \leq 0.05$.

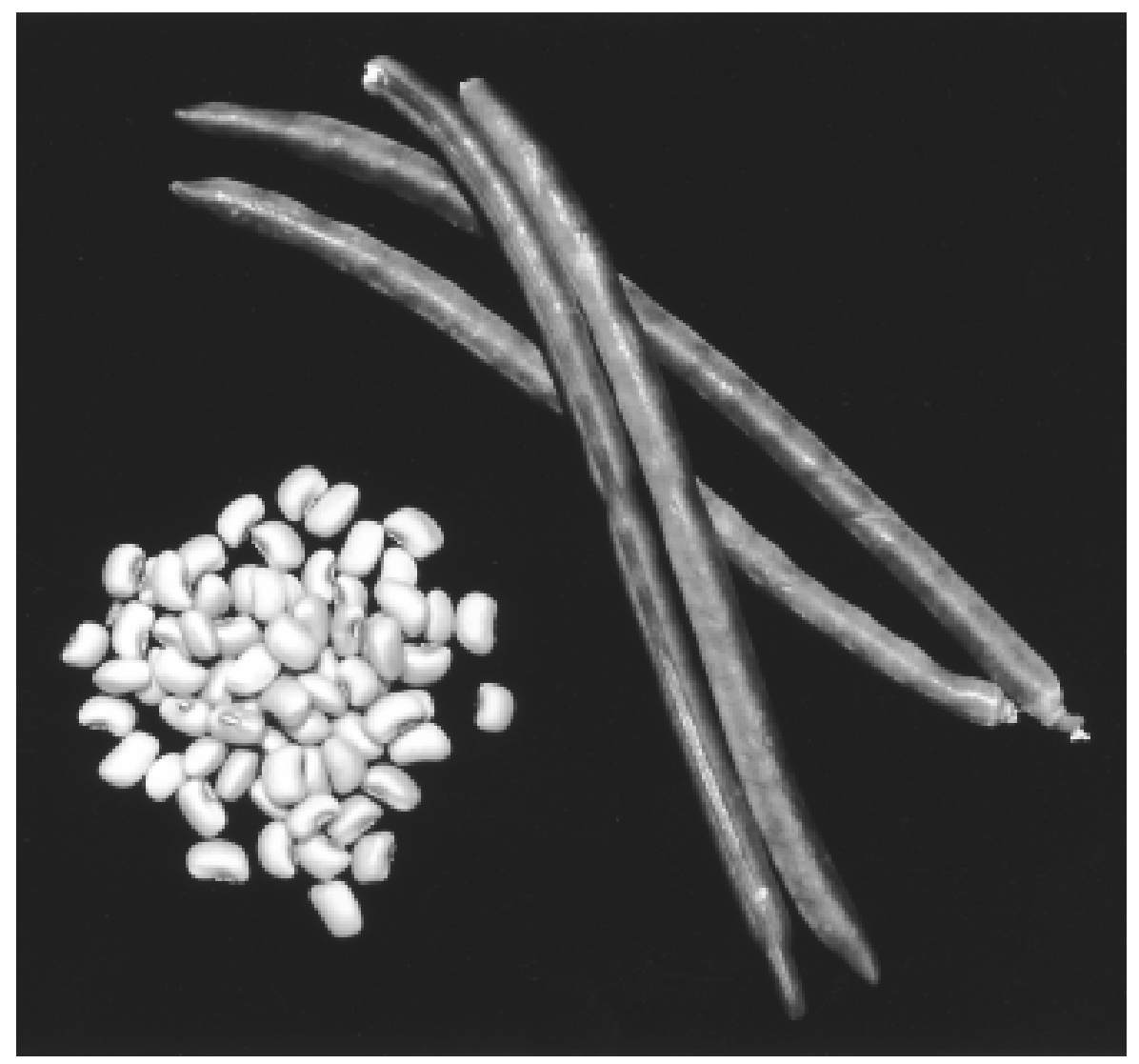


Table 2. Number of days to harvest, weight per 100 dry peas, and dry pea yield for 'Green Pixie', 'White Acre', and 'Bettergreen' southernpeas grown in replicated trials, Charleston, S.C., 1996-98.'

\begin{tabular}{|c|c|c|c|}
\hline Cultivar & Days to harvest (no.) & $\mathrm{Wt} / 100$ dry peas $(\mathrm{g})$ & Dry pea yield $\left(\mathrm{kg} \cdot \mathrm{ha}^{-1}\right)$ \\
\hline \multicolumn{4}{|c|}{ Trial I-1996 } \\
\hline Green Pixie & $75.4 b^{y}$ & $6.5 \mathrm{c}$ & $982 \mathrm{a}$ \\
\hline White Acre & $80.0 \mathrm{a}$ & $7.9 \mathrm{~b}$ & $666 \mathrm{~b}$ \\
\hline Bettergreen & $73.0 \mathrm{c}$ & $9.4 \mathrm{a}$ & $1082 \mathrm{a}$ \\
\hline \multicolumn{4}{|c|}{ Trial II-1997 } \\
\hline Green Pixie & $73.6 \mathrm{~b}$ & $6.6 \mathrm{~b}$ & $725 \mathrm{a}$ \\
\hline White Acre & $81.0 \mathrm{a}$ & --- & $678 \mathrm{a}$ \\
\hline Bettergreen & $67.0 \mathrm{c}$ & $9.6 \mathrm{a}$ & $573 \mathrm{a}$ \\
\hline \multicolumn{4}{|c|}{ Trial III-1998 } \\
\hline Green Pixie & $77.5 \mathrm{~b}$ & $8.7 \mathrm{~b}$ & $893 \mathrm{~b}$ \\
\hline White Acre & $81.0 \mathrm{a}$ & $8.1 \mathrm{c}$ & $1047 \mathrm{a}$ \\
\hline Bettergreen & $68.3 \mathrm{c}$ & $10.5 \mathrm{a}$ & $871 \mathrm{~b}$ \\
\hline \multicolumn{4}{|c|}{ Trial IV-1998 } \\
\hline Green Pixie & $75.9 \mathrm{~b}$ & $7.9 \mathrm{~b}$ & 1138 a \\
\hline White Acre & $79.9 \mathrm{a}$ & $7.7 \mathrm{~b}$ & $1348 \mathrm{a}$ \\
\hline Bettergreen & $74.0 \mathrm{~b}$ & $10.5 \mathrm{a}$ & $1265 \mathrm{a}$ \\
\hline \multicolumn{4}{|c|}{ Combined analysis of all trials ${ }^{x}$} \\
\hline Green Pixie & $75.6 \mathrm{~b}^{* * *}$ & $8.0 \mathrm{~b}^{* * *}$ & $928 \mathrm{a}^{* *}$ \\
\hline White Acre & $80.5 \mathrm{a}$ & $7.9 \mathrm{~b}$ & $973 \mathrm{a}$ \\
\hline Bettergreen & $70.2 \mathrm{c}$ & $10.2 \mathrm{a}$ & $928 \mathrm{a}$ \\
\hline
\end{tabular}

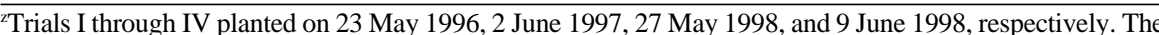
experimental design of each trial was a randomized complete block with five (1996) or 10 (1997 and 1998 ) replications. Results of combined analyses of all trials indicated a significant cultivar $\times$ trial interaction for all variables. Consequently, results are presented for both single trial and combined analyses to aid interpretation. ${ }^{y}$ Mean separation within columns and trials by Student-Newman-Keuls multiple range test, $P \leq 0.05$.

xThe combined analysis for weight per 100 dry peas does not include the 1997 data set (Trial II).

***,*** Interaction between cultivar and trial significant at $P \leq 0.01$ and 0.001 , respectively.

entry (18 location-years), the yield of 'Green Pixie' averaged $86 \%$ of that of the cream-type control ('Early Acre' or 'White Acre').

'Green Pixie', like its 'Bettergreen' parent, is homozygous for the $g c$ gene that conditions the green cotyledon trait (Fery and Dukes, 1994). Seedcoats and cotyledons of field-grown 'Green Pixie' peas harvested at the dry-stage of maturity are light olive in color, whereas those of 'White Acre' peas harvested at a similar stage of maturity are a cream color. Dry 'Green Pixie' peas imbibed to restore fresh-harvest seed size and blanched in boiling water for $3 \mathrm{~min}$, exhibit a near-fresh green color; similarly treated 'White Acre' peas have a cream color.
'Green Pixie' is recommended particularly for use by the frozen food industry as a substitute for 'Bettergreen' when grown to produce the raw product for a blended pack of 'Bettergreen' and 'White Acre' peas. 'Green Pixie' is the only cream-type, greencotyledon phenotype cultivar available that yields peas that are similar in size and shape to 'White Acre' peas. In production areas where the yield potential is acceptable, 'Green Pixie' is recommended for trial as a replacement for 'White Acre' when grown to produce raw product for a frozen pack.

\section{Availability}

Breeder's seed of 'Green Pixie' has been released to seed producers. Small samples of 'Green Pixie' breeder's seed are available from the author for distribution to all interested research personnel. Genetic material of this release will be deposited in the National Plant Germplasm System, where it will be available for research purposes, including the development and commercialization of new cultivars. It is requested that appropriate recognition of source be given when this germplasm contributes to research or development of a new breeding line or cultivar.

\section{Literature Cited}

Fery, R.L. and P.D. Dukes. 1994. Genetic analysis of the green cotyledon trait in southernpea [Vigna unguiculata $(\mathrm{L}$.) Walp.]. J. Amer. Soc. Hort. Sci. 119:1054-1056.

Fery, R.L., P.D. Dukes, and F.P. Maguire. 1993. 'Bettergreen' southernpea. HortScience 28:856. 